\title{
Ochrobactrum pseudintermedium sp. nov., a novel member of the family Brucellaceae, isolated from human clinical samples
}

\author{
Corinne Teyssier, ${ }^{1}$ Hélène Marchandin, ${ }^{2}$ Hélène Jean-Pierre, ${ }^{2}$ \\ Agnès Masnou, ${ }^{1}$ Ghislaine Dusart ${ }^{1}$ and Estelle Jumas-Bilak ${ }^{1}$ \\ ${ }^{1}$ Université Montpellier 1, Laboratoire de Bactériologie-Virologie, EA3755, Faculté de \\ Pharmacie, 15 Avenue Charles Flahault, BP 14491, F-34093 Montpellier Cedex 5, France \\ ${ }^{2} \mathrm{CHU}$ de Montpellier, Laboratoire de Bactériologie, Hôpital Arnaud de Villeneuve, 371 Avenue \\ du doyen Gaston Giraud, F-34295 Montpellier Cedex 5, France
}

Correspondence Corinne Teyssier corinne.teyssier@univ-montp1.fr
The genus Ochrobactrum belongs to the family Brucellaceae in the class Alphaproteobacteria. It currently comprises seven species that were isolated from a wide variety of environmental sources (soil, rhizosphere) (Lebuhn et al., 2000), as well as from plants (Trujillo et al., 2005; Tripathi et al., 2006), animals (Kämpfer et al., 2003) and humans (Holmes et al., 1988; Velasco et al., 1998). To date, Ochrobactrum anthropi and Ochrobactrum intermedium are the only species to be recovered from human clinical samples (Teyssier et al., 2005a). In this study, we characterized three strains of an Ochrobactrum sp. that were isolated from two patients hospitalized in intensive-care units of the Montpellier University Hospital, France. We used genetic, phylogenetic, genomic and phenotypic analyses to compare these strains

The GenBank/EMBL/DDBJ accession numbers for the $16 \mathrm{~S}$ rRNA, $d n a K$ and $r p o B$ gene sequences of strain $A D V 31^{\top}$ are DQ365921, D0393570 and DQ926698, respectively; those for strain ADV41 are D0365922, D0393571 and D0926699, respectively; and those for strain ADV43 are DQ365923, D0393572 and D0926700, respectively.

A phylogenetic tree based on concatenated $d n a K$ and $r p o B$ gene sequences of strains $A D V 31^{\top}, A D 41$ and $A D 43$ and other members of the genera Ochrobactrum and Brucella, a schematic representation of the rrn skeleton of the two chromosomes of strain $A D V 31^{\top}$ and a twodimensional thin-layer chromatogram of the polar lipids of strain $\mathrm{ADV} 31^{\top}$ are available as supplementary figures in IJSEM Online. with known Ochrobactrum species. This study led to the description of a novel species in the genus Ochrobactrum.

The three isolates were recovered from samples taken during the standard procedure for the detection of multiresistant bacilli carriage in patients hospitalized in intensivecare units. The strains grew after incubation for $24-48 \mathrm{~h}$ at $37^{\circ} \mathrm{C}$ on Drigalski agar (Difco), supplemented with $4 \mathrm{mg}$ ceftazidime $\mathrm{l}^{-1}$, a medium that is selective for multiresistant, non-exigent, Gram-negative bacteria. Strain ADV31 ${ }^{\mathrm{T}}$ was isolated in 2002 from an axillary swab from a 20-year-old man. Isolates ADV41 and ADV43 were recovered in 2003 from rectal swabs taken $48 \mathrm{~h}$ apart from a 25-year-old man hospitalized in a different intensivecare unit. PFGE of SpeI-restricted DNA performed as described previously (Teyssier et al., 2003a) showed that strains ADV41 and ADV43 were not related (data not shown).

Genomic DNA used for PCR was obtained using an AquaPure genomic DNA isolation kit (Bio-Rad). Amplification of the 16S rRNA gene was performed using the universal primers $27 \mathrm{f}$ and 1492r (Teyssier et al., 2003a) or primers F4 and R2 that are described as being specific for Brucella spp. and O. intermedium (Romero et al., 1995; Velasco et al., 1998). Partial dnaK (encoding the $70 \mathrm{kDa}$ heat-shock protein) and $r p o B$ (encoding the DNA-dependent RNA polymerase $\beta$-subunit) gene amplifications 
were carried out with primers 289f (5'-ATCGTCAAGGGCGACAATGGC-3')/1142r (5'-CGTCCTTGACGTCGCCCTGCA-3') and 453f (5'-ATCGTTTCGCAGATGCACCG-3')/1232r (5'-CGCATGTTCATCTTCACGCGGCC-3'), respectively. The PCR reactions were all performed as described previously for 16S rRNA gene amplification (Teyssier et al., 2003a). Sequencing was done in both directions with forward and reverse primers using an Applied Biosystems Automatic Sequencer (Genome Express). Partial 16S rRNA gene sequences of about 1400 bp were compared with sequences deposited in GenBank/EMBL/DDBJ using the standard BLAST program (www.ncbi.nlm.nih.gov/blast) and LALIGN software (www.expasy.org). The three isolates, ADV $31^{\mathrm{T}}$, ADV41 and ADV43, shared more than $99.8 \%$ of their nucleotide positions. The highest 16S rRNA gene sequence similarity was obtained with the type strain of O. intermedium (97.48\%). However, PCR using primers F4 and R2 was negative for strains ADV31 $1^{\mathrm{T}}$, ADV41 and ADV43, clearly differentiating these strains from $O$. intermedium (Velasco et al., 1998). The dnaK and rpoB sequences also distinguished strain $\mathrm{ADV} 31^{\mathrm{T}}$ from other members of the genus Ochrobactrum, as the maximum similarity levels were $95.5 \%$ with O. intermedium for $d n a K$ and $93.6 \%$ with $O$. anthropi for $r p o B$. The similarity levels among strains $\mathrm{ADV} 31^{\mathrm{T}}$, ADV41 and ADV43 were greater than 98.9 and $97.5 \%$ for $d n a K$ and $r p o B$, respectively. $16 \mathrm{~S}$ rRNA gene-, dnaK- and rpoB-based phylogenies were used to analyse the relationships between the three clinical isolates and members of the genera Ochrobactrum and Brucella. A single dnaK- and rpoB-based tree was reconstructed using a concatenation of $d n a K$ and $r p o B$ sequences. A distance matrix was calculated using the F84 algorithm (Kishino \& Hasegawa, 1989) in the DNADIST program after sequence alignment with CLUSTAL_X (Thompson et al., 1997). The neighbour-joining method (Saitou \& Nei, 1987) was used to reconstruct distance trees. The results were compared with trees obtained using parsimony (Kluge \& Farris, 1969) and maximum-likelihood (Olsen et al., 1994) with the programs DNAPARS and fastDNAml, respectively. The robustness of the trees was evaluated by bootstrap analysis of 1000 replicates using the programs SEQBOOT and CONSENSE. All the phylogenetic programs used were from PHYLIP package 3.66 (Felsenstein, 1993). Independent of methods and markers, strains ADV $31^{\mathrm{T}}$, ADV41 and ADV43 were grouped in a lineage that was distinct from other species of the genus Ochrobactrum and supported by high bootstrap values (Fig. 1 and Supplementary Fig. S1 in IJSEM Online). The phylogenetic analysis showed that isolates ADV $31^{\mathrm{T}}$, ADV41 and ADV43 should be considered as representing a novel species in the genus Ochrobactrum. Independent lineages, each corresponding to a single Ochrobactrum species, were observed in all the trees reconstructed, except for Ochrobactrum lupini, which formed a monophyletic group with O. anthropi ATCC $49188^{\mathrm{T}}$ (Fig. 1 and

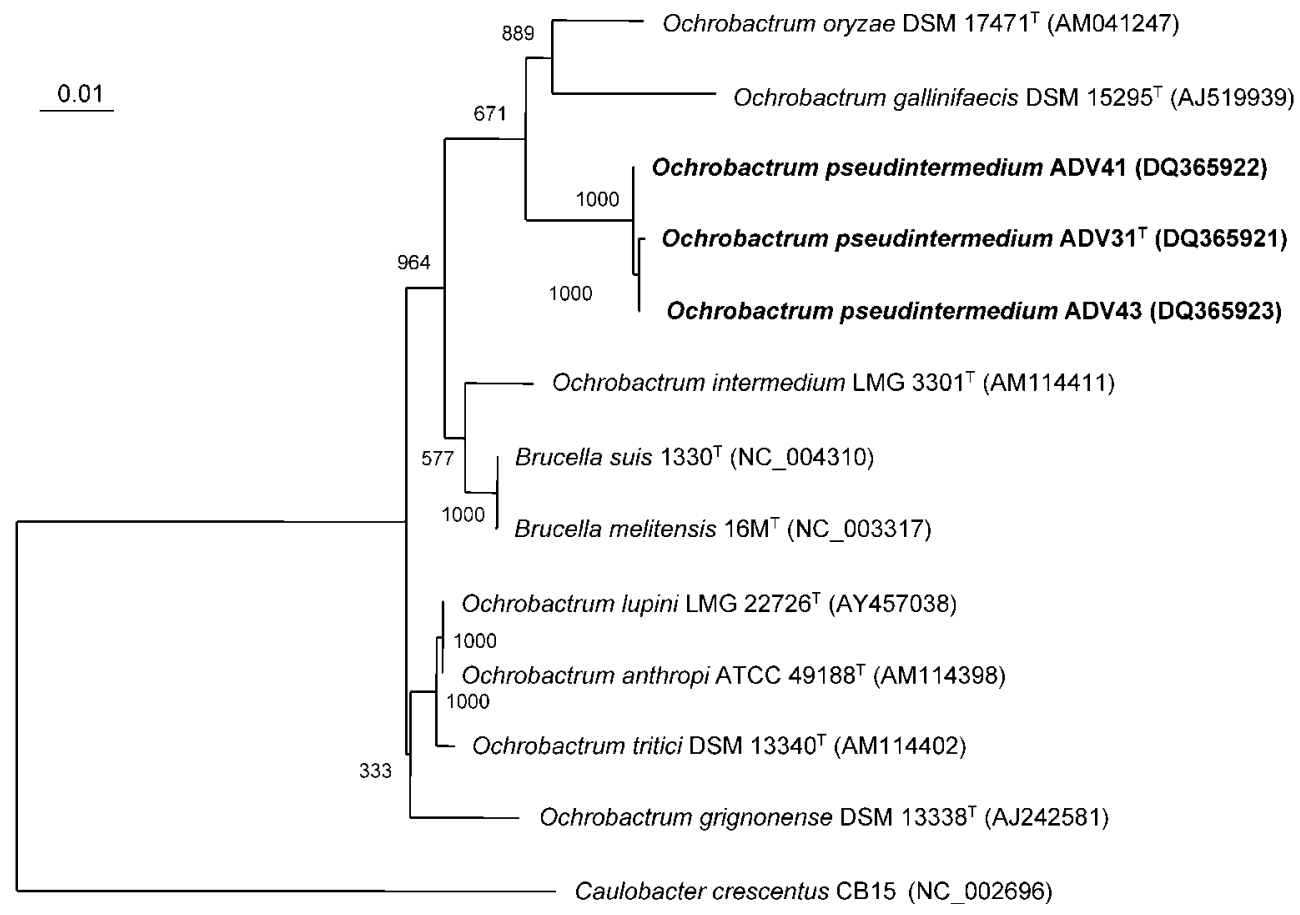

Fig. 1. Phylogenetic tree based on partial $16 \mathrm{~S}$ rRNA gene (1351 bp) sequence comparison showing the relationships between strains ADV $31^{\top}, \operatorname{ADV} 41$ and $\operatorname{ADV} 43$ (O. pseudintermedium sp. nov.) and members of the genera Ochrobactrum and Brucella. The tree was obtained using the neighbour-joining method with F84 algorithm. GenBank accession numbers are given in parentheses. Numbers at nodes are bootstrap values based on 1000 resamplings. Bar, 0.01 substitutions per nucleotide position. The sequence of Caulobacter crescentus CB15 was used as an outgroup. 
Supplementary Fig. S1 in IJSEM Online). The relative branching of $O$. intermedium and Ochrobactrum grignonense differed between $16 \mathrm{~S}$ rRNA- and dnak-rpoB-based trees. The dnak-rpoB-based tree displayed higher bootstrap values than those obtained in the 16S rRNA gene-based tree. This confirmed that the evolutionary relationships among members of the genus Ochrobactrum cannot be resolved using the 16S rRNA gene alone. In addition to recA (Scholz et al., 2006), the two markers proposed herein are useful for studying species diversity in the genus Ochrobactrum. Additional comparative sequence analysis showed that $16 \mathrm{~S}$ rRNA gene sequences deposited in databases for strains that have not been identified to the species level matched the sequences of the clinical isolates studied. These sequences were used to reconstruct a $16 \mathrm{~S}$ rRNA gene-based tree (data not shown). The tree showed that Ochrobactrum strain CGL-X (GenBank accession no. DQ305290) might represent another member of the novel species, as well as strain TKW2 (AY631061) deposited as Rhizobium sp. and strain YBJCA-1 (DQ305284) deposited as Brucella sp.

Strains ADV31 ${ }^{\mathrm{T}}$, ADV41 and ADV43 were compared with the type strains of other Ochrobactrum species: O. anthropi ATCC $49188^{\mathrm{T}}$, O. intermedium LMG $3301^{\mathrm{T}}$, O. grignonense DSM $13338^{\mathrm{T}}$, Ochrobactrum tritici DSM $13340^{\mathrm{T}}$, Ochrobactrum gallinifaecis DSM $15295^{\mathrm{T}}$ and O. lupini LMG $22726^{\mathrm{T}}$. Data from the literature were used to compare the three strains with the recently described species Ochrobactrum oryzae (Tripathi et al., 2006).

DNA-DNA hybridization between $O$. intermedium LMG $3301^{\mathrm{T}}$ and strain $\mathrm{ADV} 31^{\mathrm{T}}$ was performed, according to the methods of De Ley et al. (1970) with the modifications of Huß et al. (1983), at the Identification Service of the Deutsche Sammlung von Mikroorganismen und Zellkulturen (DSMZ; Germany). The values obtained in duplicate experiments were 37.7 and $48.2 \%$, confirming that isolate $\mathrm{ADV} 31^{\mathrm{T}}$ does not belong to the species $O$. intermedium. The DNA G $+C$ content of strain ADV $31^{\mathrm{T}}$, determined by HPLC (Mesbah et al., 1989), was $54.5 \mathrm{~mol} \%$, a value that was different from those reported for other members of the genus Ochrobactrum (Table 1).

Intact genomic DNA of strains $\mathrm{ADV} 31^{\mathrm{T}}, \mathrm{ADV} 41$ and ADV43 was subjected to PFGE in order to count and size large replicons (Teyssier et al., 2005b). The rrn skeleton was constructed as described previously (Teyssier et al., 2003b, 2005b). The genomes of the three clinical strains harboured two circular chromosomes of about 2.8 and $1.78 \mathrm{Mb}$. In addition, strain $\mathrm{ADV} 31^{\mathrm{T}}$ possessed a plasmid of $0.44 \mathrm{Mb}$. I$\mathrm{Ceu} \mathrm{I}$ digestion led to four restriction fragments, indicating the presence of four rrn copies in the genome of the three strains. Two $r r n$ copies were located on each chromosome (see Supplementary Fig. S2 in IJSEM Online). These results were in agreement with the affiliation of the isolates to the genus Ochrobactrum. Indeed, the bipartite organization of the genome and the rrn skeleton of the large chromosome have been described previously as being characteristic of this genus (Teyssier et al., 2005b). The rrn organization of the small chromosome was identical to that of O. anthropi, O. grignonense, O. tritici and O. lupini, but was different from that of O. intermedium and O. gallinifaecis (Teyssier et al., 2005b).

Cells of strains ADV $31^{\mathrm{T}}$, ADV41 and ADV43 were Gramnegative, straight or slightly curved short rods, with one flame-shaped end. The cells appeared to be motile under microscopic observation and after culture on mannitol motility nitrate broth medium (Bio-Rad). Electron microscopy after negative staining, performed as described previously (Marchandin et al., 2003) and observed with a Hitachi H7100 electron microscope, showed the presence of one or two flagella in a subterminal position. Cells were $0.65-0.75 \times 1.5-1.7 \mu \mathrm{m}$ in size. The strains were cultivated on tryptic soy agar (Difco) at $25,30,37$ and $45^{\circ} \mathrm{C}$. Colonies were non-pigmented, mucoid and opaque. The three strains grew on MacConkey medium (Difco) only at $37^{\circ} \mathrm{C}$ and did not grow on cetrimid agar (Difco), independent of the incubation temperature. General metabolic characteristics were common to those of all members of the genus Ochrobactrum: aerobic respiration, presence of catalase and cytochrome oxidase, oxidative metabolism and acids not being produced from carbohydrates on the API 20E system (bioMérieux). Eighty-one biochemical characteristics were determined using the API 20E and API 20NE systems and VITEK 2 with ID-GN card version WSVT2-R04.01 (bioMérieux), according to the manufacturer's instructions. A comparison of the data obtained for strains $A D V 31^{\mathrm{T}}$, ADV41 and ADV43 and those for the type strains of other Ochrobactrum species is given in Table 1. The antimicrobial susceptibility pattern was determined by using the discdiffusion assay on Mueller-Hinton agar, according to the recommendations of the SFM antibiogram committee for Gram-negative non-fermenters (Members of the SFM Antibiogram Committee, 2003). Antibiotic susceptibility patterns for strains ADV31 ${ }^{\mathrm{T}}$, ADV41 and ADV43 and other Ochrobactrum species are compared in Table 1. As generally observed for the genus Ochrobactrum, the three isolates were resistant to all $\beta$-lactams except imipenem $(10 \mu \mathrm{g})$ (Teyssier et al., 2005a). They were also resistant to colistin $(50 \mu \mathrm{g})$ and susceptible to tobramycin $(10 \mu \mathrm{g})$ and netilmicin $(30 \mu \mathrm{g})$. This pattern differentiated strains ADV $31^{\mathrm{T}}, \mathrm{ADV} 41$ and ADV43 from the two other Ochrobactrum species recovered from human clinical samples (Teyssier et al., 2005a). Indeed, $O$. anthropi strains were susceptible to colistin, tobramycin and netilmicin, whereas $O$. intermedium strains were resistant to these three antibiotics (Teyssier et al., 2005a). Moreover, strains $\mathrm{ADV} 31^{\mathrm{T}}, \mathrm{ADV} 41$ and $\mathrm{ADV} 43$ were resistant to tetracycline $(30 \mu \mathrm{g})$, unlike other Ochrobactrum species.

Chemotaxonomic analyses of strain $\mathrm{ADV} 31^{\mathrm{T}}$, including fatty acid methyl esters, respiratory quinones and polar lipids, were performed at the Identification Service of the DSMZ, according to Tindall (1990a, b) and Kämpfer et al. (1994). Predominant cellular fatty acids were $\mathrm{C}_{19: 0}$ cyclo $\omega 8 c$ and $\mathrm{C}_{18: 1} \omega 7 c$, constituting 39.8 and $29.3 \%$ of the total fatty acid methyl esters, respectively. Other fatty acids were 
Table 1. Phenotypic characteristics and DNA base composition of O. pseudintermedium sp. nov. (strains $A D V 31^{\top}$, ADV41 and ADV43) and the type strains of other Ochrobactrum species

Strains: 1, ADV31 ${ }^{\mathrm{T}} ; 2$, ADV41; 3, ADV43; 4, O. intermedium LMG $3301^{\mathrm{T}} ; 5$, O. anthropi ATCC 49188 ${ }^{\mathrm{T}} ; 6$, O. grignonense DSM 13338 ${ }^{\mathrm{T}}$; 7 , O. tritici DSM $13340^{\mathrm{T}}$; 8, O. gallinifaecis DSM $15295^{\mathrm{T}}$; 9, O. lupini LMG $22726^{\mathrm{T}}$. +, Positive reaction; -, negative reaction; R, resistant; S, susceptible; I, intermediate; ND, not determined. All strains are positive for activities of cytochrome oxidase, catalase, glycine arylamidase ${ }^{*}$, L-proline arylamidase ${ }^{\star}$ and tyrosine arylamidase ${ }^{\star}$, and assimilation of glucose $\dagger$, arabinose $\dagger$, mannose $\dagger$, malate $\dagger$ and potassium gluconate $\dagger$. All strains are positive for alkalinization of L-lactate ${ }^{\star}$ and succinate ${ }^{\star}$. All strains are negative for production of indole $\dagger$, acetoin $\dagger$ and $\mathrm{H}_{2} \mathrm{~S} \dagger$, hydrolysis of gelatin $\dagger$, assimilation of adipic acid $\dagger$, phenylacetic acid $\dagger$, L-histidine and L-lactate, and fermentation of carbohydrates $\dagger$. All strains are negative for DNase, phenylalanine deaminase, tryptophan deaminase $\dagger$, arginine dihydrolase $\dagger$, Ala-Phe-Pro arylamidase ${ }^{\star}$, glutamyl arylamidase $\mathrm{pNA}^{\star}, \beta$-xylosidase ${ }^{\star}$, lipase ${ }^{\star}, N$-acetyl- $\beta$-galactosaminidase ${ }^{\star}, \alpha$-galactosidase ${ }^{\star}, \beta$-galactosidase $(\mathrm{ONPG}) \dagger, N$-acetyl- $\beta$-glucosaminidase $^{\star}$, phosphatase ${ }^{\star}$, ornithine decarboxylase ${ }^{\star}$, lysine decarboxylase ${ }^{\star}, \beta$-glucuronidase ${ }^{\star}$ and $\beta$-glucosidase (aesculin hydrolysis) $\dagger$, and for acidification of L-arabitol ${ }^{\star}, \mathrm{D}$-cellobiose ${ }^{\star}, \mathrm{D}$-mannitol ${ }^{\star}, \mathrm{D}_{\text {-trehalose }}$, malonate ${ }^{\star}, 5$-keto-D-gluconate ${ }^{\star}$ and coumarate ${ }^{\star}$. All strains are susceptible to vibriostatic compound $\mathrm{O} / 129^{\star}$. All strains are susceptible to gentamicin, nalidixic acid, pefloxacin, ofloxacin, ciprofloxacin and rifampicin and all are resistant to fosfomycin.

\begin{tabular}{|c|c|c|c|c|c|c|c|c|c|}
\hline Characteristic & 1 & 2 & 3 & $4 \ddagger$ & $5 \neq$ & $6 \ddagger$ & $7 \ddagger$ & $8 \neq$ & 9 \\
\hline Growth at $45^{\circ} \mathrm{C}$ & + & + & + & + & - & - & - & - & - \\
\hline Urease activity $\dagger$ & - & - & - & - & + & - & + & + & + \\
\hline Nitrate reduction $\dagger$ & + & + & + & + & + & + & + & + & - \\
\hline \multicolumn{10}{|l|}{ Assimilation of: } \\
\hline D-Mannitol $\dagger$ & + & + & + & + & + & + & + & - & + \\
\hline$N$-Acetylglucosamine $\dagger$ & + & + & + & + & + & + & + & - & + \\
\hline D-Maltose $\dagger$ & + & + & + & + & + & - & + & - & + \\
\hline Capric acid $\dagger$ & + & + & + & + & + & + & + & - & + \\
\hline Trisodium citrate $\dagger$ & - & + & + & + & + & + & + & - & + \\
\hline \multicolumn{10}{|l|}{ Activity of: } \\
\hline L-Pyrrolidonyl arylamidase* & + & + & + & + & + & + & + & - & + \\
\hline Glu-Gly-Arg arylamidase ${ }^{\star}$ & - & - & - & - & - & + & - & - & - \\
\hline$\beta$-Alanine arylamidase $\mathrm{pNA}^{*}$ & - & - & - & - & + & - & - & - & + \\
\hline$\gamma$-Glutamyl transferase ${ }^{\star}$ & - & + & - & - & - & - & - & - & - \\
\hline$\alpha$-Glucosidase ${ }^{\star}$ & - & + & - & + & + & - & + & - & - \\
\hline \multicolumn{10}{|l|}{ Acidification of: } \\
\hline Adonitol $^{\star}$ & + & + & + & + & + & - & + & - & + \\
\hline D-Glucose ${ }^{*}$ & - & - & - & - & - & + & - & + & - \\
\hline D-Maltose ${ }^{*}$ & + & + & - & + & - & - & - & - & - \\
\hline D-Mannose ${ }^{\star}$ & - & - & - & - & - & + & - & - & - \\
\hline Palatinose $^{\star}$ & + & - & - & + & - & - & - & - & - \\
\hline D-Sorbitol ${ }^{*}$ & + & - & - & - & - & - & - & - & - \\
\hline Sucrose ${ }^{\star}$ & + & + & - & + & - & - & - & - & - \\
\hline D-Tagatose ${ }^{*}$ & + & + & + & + & + & + & + & - & + \\
\hline \multicolumn{10}{|l|}{ Resistance to antibiotics: } \\
\hline Amoxicillin $(25 \mu \mathrm{g})$ & $\mathrm{R}$ & S & $\mathrm{R}$ & $\mathrm{R}$ & $\mathrm{R}$ & $\mathrm{R}$ & $\mathrm{R}$ & S & $\mathrm{R}$ \\
\hline Amoxicillin/clavulanic acid $(20 \mu \mathrm{g} / 10 \mu \mathrm{g})$ & $\mathrm{R}$ & S & $\mathrm{R}$ & $\mathrm{R}$ & $\mathrm{R}$ & S & $\mathrm{R}$ & S & $\mathrm{R}$ \\
\hline Other $\beta$-lactams $\S \|$ & $\mathrm{R}$ & $\mathrm{R}$ & $\mathrm{R}$ & $\mathrm{R}$ & $\mathrm{R}$ & $\mathrm{R}$ & $\mathrm{R}$ & s & $\mathrm{R}$ \\
\hline Tobramycin $(10 \mu \mathrm{g})$ & S & S & s & $\mathrm{R}$ & s & s & s & S & s \\
\hline Netilmicin $(30 \mu \mathrm{g})$ & s & s & s & $\mathrm{R}$ & s & s & s & S & S \\
\hline Amikacin $(30 \mu \mathrm{g})$ & s & s & s & $\mathrm{R}$ & s & s & s & s & s \\
\hline Isepamicin $(30 \mu \mathrm{g})$ & S & S & s & $\mathrm{R}$ & S & S & s & s & S \\
\hline Colistin $(50 \mu \mathrm{g})$ & $\mathrm{R}$ & $\mathrm{R}$ & $\mathrm{R}$ & $\mathrm{R}$ & s & $\mathrm{R}$ & S & $\mathrm{R}$ & S \\
\hline Chloramphenicol $(30 \mu \mathrm{g})$ & $\mathrm{R}$ & $\mathrm{R}$ & $\mathrm{R}$ & $\mathrm{R}$ & $\mathrm{R}$ & I & $\mathrm{R}$ & S & $\mathrm{R}$ \\
\hline Trimethoprim-sulfamethoxazole $(1.25 \mu \mathrm{g} / 23.75 \mu \mathrm{g})$ & S & S & s & s & s & $\mathrm{R}$ & S & s & S \\
\hline Tetracycline $(30 \mu \mathrm{g})$ & $\mathrm{R}$ & $\mathrm{R}$ & $\mathrm{R}$ & S & S & S & S & I & S \\
\hline DNA G $+\mathrm{C}$ content $(\mathrm{mol} \%) \boldsymbol{g}$ & 54.5 & $\mathrm{ND}$ & $\mathrm{ND}$ & $57.7^{a}$ & $57.0^{b}$ & $58.0^{c}$ & $59.0^{c}$ & $\mathrm{ND}$ & $56.8^{d}$ \\
\hline
\end{tabular}


${ }^{\star}$ Data obtained using VITEK 2 with ID-GN card (bioMérieux).

$\dagger$ Data obtained using 20E and 20NE API systems (bioMérieux) after $48 \mathrm{~h}$ of incubation.

$\ddagger$ Data for API systems and antibiotic susceptibility are from Teyssier et al. (2005a).

$§$ Other $\beta$-lactams: aztreonam $(30 \mu \mathrm{g})$, cefalotin $(30 \mu \mathrm{g})$, cefepime $(30 \mu \mathrm{g})$, cefotaxime $(30 \mu \mathrm{g})$, cefpirome $(30 \mu \mathrm{g})$, ceftazidime $(30 \mu \mathrm{g})$, imipenem $(10 \mu \mathrm{g})$, piperacillin $(75 \mu \mathrm{g})$, piperacillin/tazobactam $(75 \mu \mathrm{g} / 10 \mu \mathrm{g})$, ticarcillin $(75 \mu \mathrm{g})$, ticarcillin/clavulanic acid $(75 \mu \mathrm{g} / 10 \mu \mathrm{g})$.

IIAll strains are susceptible to imipenem and resistant to aztreonam.

IData from: a, Velasco et al. (1998); b, Holmes et al. (1988); c, Lebuhn et al. (2000); d, Trujillo et al. (2005).

present at moderate or low amounts (Table 2). This profile was most similar to that of O. gallinifaecis, but differed from those of the type strains of other Ochrobactrum species (Kämpfer et al., 2003; Trujillo et al., 2005; Tripathi et al., 2006). Two respiratory lipoquinones, ubiquinone 10 and ubiquinone 9, were detected, at peak area ratios of 96 and $4 \%$, respectively. The presence of ubiquinone 10 as the dominant respiratory lipoquinone is characteristic of members of the Alphaproteobacteria (Lechner et al., 1995). The major polar lipids were phosphatidylglycerol, phosphatidylethanolamine and phosphatidylcholine. In addition, diphosphatidylglycerol, aminophospholipid and an unidentified aminolipid were detected in moderate amounts (see Supplementary Fig. S3 in IJSEM Online).

Table 2. Fatty acid methyl ester compositions (\%) of the type strains of Ochrobactrum species

Strains: $1, \mathrm{ADV}^{\mathrm{T}} \mathrm{1}^{\mathrm{T}}$ (O. pseudintermedium sp. nov.; data from this study); 2, O. intermedium LMG $3301^{\mathrm{T}}$ (Kämpfer et al., 2003); 3, O. anthropi ATCC $49188^{\mathrm{T}}$ (Kämpfer et al., 2003); 4, O. grignonense DSM $13338^{\mathrm{T}}$ (Kämpfer et al., 2003); 5, O. tritici DSM $13340^{\mathrm{T}}$ (Kämpfer et al., 2003); 6, O. gallinifaecis DSM $15295^{\mathrm{T}}$ (Kämpfer et al., 2003); 7, O. lupini LMG $22726^{\mathrm{T}}$ (Trujillo et al., 2005), 8, O. oryzae MTCC $4195^{\mathrm{T}}$ (Tripathi et al., 2006). -, Not detected.

\begin{tabular}{|c|c|c|c|c|c|c|c|c|}
\hline Fatty acid & 1 & 2 & 3 & 4 & 5 & 6 & 7 & 8 \\
\hline $\mathrm{C}_{13: 1}$ at $12-13$ & - & - & 0.6 & 0.7 & - & - & - & - \\
\hline $\mathrm{C}_{14: 0}$ & - & - & - & - & - & 0.7 & - & 0.1 \\
\hline $\mathrm{C}_{16: 0}$ & 12.0 & 3.7 & 6.6 & 2.9 & 3.7 & 8.9 & 4.2 & 5.1 \\
\hline $\mathrm{C}_{17: 0}$ & 3.1 & 3.1 & 1.4 & 1.7 & 0.9 & - & 1.6 & 0.3 \\
\hline $\mathrm{C}_{17: 0}$ cyclo & 1.4 & - & 0.8 & - & - & 2.9 & - & $<0.1$ \\
\hline$C_{17: 1} \omega 6 c$ & - & 1.1 & - & 0.5 & - & - & 1.4 & - \\
\hline $\mathrm{C}_{18: 0}$ & 4.2 & 4.1 & 8.8 & 7.2 & 9.6 & 3.7 & 3.0 & 5.6 \\
\hline $\mathrm{C}_{18: 1} \omega 7 c$ & 29.3 & 25.8 & 45.6 & 31.6 & 77.9 & 28.8 & 70.8 & 65.2 \\
\hline $\mathrm{C}_{18: 1} 2-\mathrm{OH}$ & 3.5 & 1.8 & 0.6 & 0.5 & 1.4 & 1.5 & 6.2 & - \\
\hline $\mathrm{C}_{18: 0} 3-\mathrm{OH}$ & 1.1 & - & - & 0.5 & - & - & 1.0 & - \\
\hline $\mathrm{C}_{19: 0}$ cyclo $\omega 8 \mathrm{c}$ & 39.8 & 57.4 & 32.7 & 50.2 & 5.9 & 47.2 & 4.3 & - \\
\hline $\mathrm{C}_{20: 1} \omega 7 c$ & - & - & - & 0.8 & - & - & - & - \\
\hline $\mathrm{C}_{20: 2} \omega 6,9 c$ & 1.4 & 0.9 & 0.5 & 0.8 & - & 1.1 & - & - \\
\hline Summed feature $2^{*}$ & 0.4 & - & - & - & - & - & 1.9 & - \\
\hline Summed feature $3^{\star}$ & 1.6 & 0.7 & 1.1 & 1.0 & 0.7 & 3.7 & 2.3 & - \\
\hline
\end{tabular}

* Summed feature 2 contains $\mathrm{C}_{12: 0}$ unknown aldehyde with ECL $10.928 / \mathrm{C}_{16: 1}$ isoI/ $\mathrm{C}_{14: 0} 3$-OH. Summed feature 3 contains $\mathrm{C}_{16: 1} \omega 7 \mathrm{cl}$ $\mathrm{C}_{15: 0}$ iso $2-\mathrm{OH}$.
The unidentified aminophospholipid in the profile of strain $\mathrm{ADV} 31^{\mathrm{T}}$ exhibited the same $R_{\mathrm{F}}$ value as that of phosphatidylmonomethylethanolamine in the polar lipid profile of O. gallinifaecis (Kämpfer et al., 2003). Consequently, we could not show any obvious differences between the polar lipid profiles of strain $\mathrm{ADV} 31^{\mathrm{T}}$ and O. gallinifaecis.

Some characteristics that are useful for the routine identification of Ochrobactrum spp. (Teyssier et al., 2005a) were common to strains ADV31 $1^{\mathrm{T}}, \mathrm{ADV} 41$ and ADV43 and $O$. intermedium (mucoid colonies, ability to grow on tryptic soy agar at $45^{\circ} \mathrm{C}$, absence of urease activity and resistance to colistin). In addition, genotyping data and phylogeny showed that the novel species was related to O. intermedium, supporting its denomination as Ochrobactrum pseudintermedium sp. nov. However, the $16 \mathrm{~S}$ rRNA gene-, dnaK- and rpoB-phylogenies, DNA-DNA hybridization, $\mathrm{G}+\mathrm{C}$ content, rrn skeleton of the small chromosome, PCR specific for Brucella spp. and O. intermedium, phenotype and chemotaxonomy clearly differentiated strains ADV $31^{\mathrm{T}}, \mathrm{ADV} 41$ and ADV43 from O. intermedium. Together, the results support the creation of a novel species to accommodate isolates $\mathrm{ADV} 31^{\mathrm{T}}, \mathrm{ADV} 41$ and ADV43 and its denomination as Ochrobactrum pseudintermedium sp. nov. is proposed.

\section{Description of Ochrobactrum pseudintermedium sp. nov.}

Ochrobactrum pseudintermedium (pseud.in'ter.med'i.um. Gr. adj. pseudos false; L. neut. adj. intermedium intermediate, and a specific epithet of the genus Ochrobactrum; N.L. neut. adj. pseudintermedium a false Ochrobactrum intermedium).

Cells are Gram-negative, non-spore forming, short rods, and motile by subpolar flagella. Cells are $0.65-0.75 \times$ $1.5-1.7 \mu \mathrm{m}$ in size. Growth occurs at $25-45^{\circ} \mathrm{C}$ on tryptic soy agar. Grows on MacConkey agar and R2A agar at $37^{\circ} \mathrm{C}$. Colonies are non-pigmented, mucoid and opaque. Aerobic respiration, oxidative metabolism, nitrate reduction and catalase and oxidase are positive. Positive for glycine arylamidase, L-proline arylamidase, tyrosine arylamidase and L-pyrrolidonyl arylamidase activities, assimilation of glucose, arabinose, mannose, malate, potassium gluconate, D-mannitol, $N$-acetylglucosamine, D-maltose and capric acid, acidification of adonitol and D-tagatose, and alkalinization of L-lactate and succinate. Negative for activities of DNase, urease, phenylalanine deaminase, tryptophan deaminase, Glu-Gly-Arg arylamidase and $\beta$-alanine arylamidase $p$-nitroanilide (pNA), arginine dihydrolase, Ala-Phe-Pro arylamidase, glutamyl arylamidase pNA, 
$\beta$-xylosidase, lipase, $N$-acetyl- $\beta$-galactosaminidase, $\alpha$-galactosidase, $\beta$-galactosidase (ONPG), $N$-acetyl- $\beta$-glucosaminidase, phosphatase, ornithine decarboxylase, lysine decarboxylase, $\beta$-glucuronidase and $\beta$-glucosidase (aesculin hydrolysis). Negative for acidification of D-glucose, Dmannose, L-arabitol, D-cellobiose, D-mannitol, D-trehalose, malonate, 5-keto-D-gluconate and coumarate, production of indole, acetoin and $\mathrm{H}_{2} \mathrm{~S}$, hydrolysis of gelatin, assimilation of adipic acid, phenylacetic acid, L-histidine and Llactate, and fermentation of carbohydrates. Resistant to $\beta$-lactams except imipenem, and to chloramphenicol, tetracycline, fosfomycin and colistin. Susceptible to aminoglycosides (gentamicin, tobramycin, netilmicin, isepamicin, amikacin), fluoroquinolones (pefloxacin, ofloxacin, ciprofloxacin), nalidixic acid, rifampicin and trimethoprimsulfamethoxazole. Major fatty acids are $\mathrm{C}_{19: 0}$ cyclo $\omega 8 \mathrm{c}$ and $\mathrm{C}_{18: 1} \omega 7 c$. Ubiquinone 10 is the dominant respiratory lipoquinone. Polar lipids mainly comprise phosphatidylglycerol, phosphatidylethanolamine and phosphatidylcholine. $16 \mathrm{~S}$ rRNA gene amplification is not obtained with primers $\mathrm{F} 4$ and R2 (Velasco et al., 1998). Genome is constituted of two chromosomes of about 2.8 and $1.8 \mathrm{Mb}$ comprising four $\mathrm{rrn}$ copies with two rrn operons in divergent orientation on the small chromosome. The $\mathrm{G}+\mathrm{C}$ content of the DNA of the type strain is $54.5 \mathrm{~mol} \%$. Can be differentiated from other species of the genus Ochrobactrum by $16 \mathrm{~S}$ rRNA, dnaK and $r p o B$ gene sequencing.

The type strain is $\operatorname{ADV}^{2} 1^{\mathrm{T}}\left(=\mathrm{CIP} 109116^{\mathrm{T}}=\mathrm{DSM} 17490^{\mathrm{T}}\right)$, which was isolated from a human clinical sample.

\section{Acknowledgements}

We gratefully acknowledge Bernard Gay for electron microscopy 'observations'. We also wish to thank Isabelle Zorgniotti and Jean-Luc Jeannot for excellent technical assistance. This work is partly supported by the association ADEREMPHA (Montpellier France).

\section{References}

De Ley, J., Cattoir, H. \& Reynaerts, A. (1970). The quantitative measurement of DNA hybridization from renaturation rates. Eur $J$ Biochem 12, 133-142.

Felsenstein, J. (1993). PHYLIP (phylogeny inference package), version 3.5c. Distributed by the author. Department of Genome Sciences, University of Washington, Seattle, USA.

Holmes, B., Popoff, M., Kiredjian, M. \& Kersters, K. (1988). Ochrobactrum anthropi gen. nov., sp. nov. from human clinical specimens and previously known as Group Vd. Int J Syst Bacteriol 38, 406-416.

Huß, V. A. R., Festl, H. \& Schleifer, K. H. (1983). Studies on the spectrophotometric determination of DNA hybridization from renaturation rates. Syst Appl Microbiol 4, 184-192.

Kämpfer, P., Blasczyk, K. \& Auling, G. (1994). Characterization of Aeromonas genomic species by using quinone, polyamine, and fatty acid patterns. Can J Microbiol 40, 844-850.

Kämpfer, P., Buczolits, S., Albrecht, A., Busse, H. J. \& Stackebrandt, E. (2003). Towards a standardized format for the description of a novel species (of an established genus):
Ochrobactrum gallinifaecis sp. nov. Int J Syst Evol Microbiol 53, 893-896.

Kishino, H. \& Hasegawa, M. (1989). Evaluation of the maximum likelihood estimate of the evolutionary tree topologies from DNA sequence data, and the branching order in Hominoidea. J Mol Evol 29, 170-179.

Kluge, A. \& Farris, J. (1969). Quantitative phyletics and the evolution of anurans. Syst Zool 18, 1-32.

Lebuhn, M., Achouak, W., Schloter, M., Berge, O., Meier, H., Barakat, M., Hartmann, A. \& Heulin, T. (2000). Taxonomic characterization of Ochrobactrum sp. isolates from soil samples and wheat roots, and description of Ochrobactrum tritici sp. nov. and Ochrobactrum grignonense sp. nov. Int J Syst Evol Microbiol 50, 2207-2223.

Lechner, U., Baumbach, R., Becker, D., Kitunen, V., Auling, G. \& Salkinoja-Salonen, M. (1995). Degradation of 4-chloro-2-methylphenol by an activated sludge isolate and its taxonomic description. Biodegradation 6, 83-92.

Marchandin, H., Jumas-Bilak, E., Gay, B., Teyssier, C., Jean-Pierre, H., Siméon de Buochberg, M., Carrière, C. \& Carlier, J. P. (2003). Phylogenetic analysis of some Sporomusa sub-branch members isolated from human clinical specimens: description of Megasphaera micronuciformis sp. nov. Int J Syst Evol Microbiol 53, 547-553.

Members of the SFM Antibiogram Committee (2003). Members of the SFM Antibiogram Committee report 2003. Int J Antimicrob Agents 21, 364-391.

Mesbah, M., Premachandran, U. \& Whitman, W. B. (1989). Precise measurement of the $\mathrm{G}+\mathrm{C}$ content of deoxyribonucleic acid by high performance liquid chromatography. Int J Syst Bacteriol 39, 159-167.

Olsen, G. J., Matsuda, H., Hagstrom, R. \& Overbeek, R. (1994). fastDNAml: a tool for construction of phylogenetic trees of DNA sequences using maximum likelihood. Comput Appl Biosci 10, 41-48.

Romero, C., Gamazo, C., Pardo, M. \& Lopez-Goni, I. (1995). Specific detection of Brucella DNA by PCR. J Clin Microbiol 33, 615-618.

Saitou, N. \& Nei, M. (1987). The neighbor-joining method: a new method for reconstructing phylogenetic trees. Mol Biol Evol 4, 406-425.

Scholz, H. C., Tomaso, H., Dahouk, S. A., Witte, A., Schloter, M., Kämpfer, P., Falsen, E. \& Neubauer, H. (2006). Genotyping of Ochrobactrum anthropi by recA-based comparative sequence, PCRRFLP, and 16S rRNA gene analysis. FEMS Microbiol Lett 257, 7-16.

Teyssier, C., Jumas-Bilak, E., Marchandin, H., Jean-Pierre, H., Jeannot, J.-L., Dusart, G., Foulongne, V. \& Siméon de Buochberg, M. (2003a). Species identification and molecular epidemiology of bacteria belonging to Ochrobactrum genus. Pathol Biol 51, 5-12.

Teyssier, C., Marchandin, H., Siméon de Buochberg, M., Ramuz, M. \& Jumas-Bilak, E. (2003b). Atypical 16S rRNA gene copies in Ochrobactrum intermedium strains reveal a large genomic rearrangement by recombination between $\mathrm{rrn}$ copies. J Bacteriol 185, 2901-2909.

Teyssier, C., Marchandin, H., Jean-Pierre, H., Darbas, H., Siméon de Buochberg, M., Diego, I., Gouby, A. \& Jumas-Bilak, E. (2005a). Molecular and phenotypic features for identification of the opportunistic pathogens Ochrobactrum spp. J Med Microbiol 54, 945-953.

Teyssier, C., Marchandin, H., Masnou, A., Jeannot, J.-L., Siméon de Buochberg, M. \& Jumas-Bilak, E. (2005b). Pulsed-field gel electrophoresis to study the diversity of whole genome organization in the genus Ochrobactrum. Electrophoresis 26, 2898-2907.

Thompson, J. D., Gibson, T. J., Plewniak, F., Jeanmougin, F. \& Higgins, D. G. (1997). The CLUSTAL_X windows interface: flexible strategies for multiple sequence alignment aided by quality analysis tools. Nucleic Acids Res 25, 4876-4882. 
Tindall, B. J. (1990a). A comparative study of the lipid composition of Halobacterium saccharovorum from various sources. Syst Appl Microbiol 13, 128-130.

Tindall, B. J. (1990b). Lipid composition of Halobacterium lacusprofundi. FEMS Microbiol Lett 66, 199-202.

Tripathi, A. K., Verma, S. C., Chowdhury, S. P., Lebuhn, M., Gattinger, A. \& Schloter, M. (2006). Ochrobactrum oryzae sp. nov., an endophytic bacterial species isolated from deep-water rice in India. Int J Syst Evol Microbiol 56, 1677-1680.
Trujillo, M. E., Willems, A., Abril, A., Planchuelo, A. M., Rivas, R., Ludena, D., Mateos, P. F., Martinez-Molina, E. \& Velazquez, E. (2005). Nodulation of Lupinus albus by strains of Ochrobactrum lupini sp. nov. Appl Environ Microbiol 71, 1318-1327.

Velasco, J., Romero, C., Lopez-Goni, I., Leiva, J., Diaz, R. \& Moriyon, I. (1998). Evaluation of the relatedness of Brucella spp. and Ochrobactrum anthropi and description of Ochrobactrum intermedium sp. nov., a new species with a closer relationship to Brucella spp. Int J Syst Bacteriol 48, 759-768. 